\title{
Research on Course Content of Administrative Law and Administrative Litigation Law of Public Security Colleges under the Background of "enrollment training system reform"
}

\author{
Qiao Wang \\ National Police University of China, Shenyang 110854, China
}

Keywords: Public security enrollment, system reform; course content; study

\begin{abstract}
The enrollment training system reform of public security colleges puts forward new requirements on the talents mode, training standard and curriculum setting and requires the nationwide public security colleges vigorously promote the new round of teaching course reform, which is a historic change of the public security talents training mode in China. According to the teaching experience and the spirit of relevant documents of public security department, the teaching course setting of Administrative Law and Administrative Litigation Law of public security colleges under the background of enrollment training system reform is studied in this paper.
\end{abstract}

\section{Introduction}

The real meaning of "enrollment training system reform" of public security colleges is "police enrollment", that is, the junior college graduates, graduates, postgraduates and professional soldiers that satisfy the application requirements are admitted by the public security colleges that are responsible for training and then distributed in a directional manner according to the applied position after two years' legal knowledge learning and public security skill training freely and finally become the official police after passing the probation. Ministry of Public Security launches Opinions on Formulating the Professional Scheme of Enrollment Training System Reform Pilot of Public Security Colleges, which makes new rules on the training goal, training standard, training mode, course setting, teaching process, teaching and assessment of public security colleges after "enrollment training system reform". Therefore, the course reform of Administrative Law and Administrative Litigation Law of public security colleges is imperative.

Necessity of research on course content of Administrative Law and Administrative Litigation Law of public security colleges under the background of "enrollment training system reform"

Administrative Law and Administrative Litigation Law has complex content, but the course setting and class distribution of each specialty of public security colleges after "enrollment training system reform" are less. Therefore, the course content must be integrated and adjusted. The importance of course content is conspicuous, which is the basis for teaching activity and also the decisive factor of achieving the course training objective. Administrative Law and Administrative Litigation Law is consisted of Administrative Law and Administrative Litigation Law, so its course content is complex. However, the class hour under the background of "enrollment training system reform" is compress, so it is impossible to teach this course well and make students really accept the course content without new round of research and integration. Therefore, it is urgent to conduct new round of research and integration of course content. 
Comprehensive analysis of the guiding thought of the curriculum design of Administrative Law and Administrative Litigation Law

\begin{abstract}
The course should choose the teaching content with cultivation of students' administrative law enforcement ability as the core

Under the contemporary social background, China's legal education pays more attention to the all-around development of people with quality-oriented education as the concept. The quality education aims at cultivating high-quality and high-ability compound talents. To avoid the phenomenon of high scores and low abilities, the cultivation of students' legal professional ability should be enhanced. The legal education of public security colleges after "enrollment training system reform" differs from the ordinary colleges greatly, but I think it is the same in the cultivation of students' legal ability and excellent compound talents. Therefore, I think Administrative Law and Administrative Litigation Law of public security colleges under the background of "enrollment training system reform" should be designed around the core of cultivating students' administrative law enforcement ability.
\end{abstract}

The course should be designed combined with the actual needs of public security law enforcement

Reform is to make the existing system more adapt to the social development and promote the social progress. The "enrollment training system reform" aims at promoting the development of public security colleges and providing more useful talents for the state and society. After the historic change of this enrollment training system, the graduates of public security colleges will enter the police troops and engage in the public security works of different level at different regions. The public security work mainly includes criminal justice and administrative law enforcement. In the real life, police officers engaging in administrative law enforcement are more than those engaging in criminal justice and other works. This determines that Administrative Law and Administrative Litigation Law has an important position in the course system of public security colleges after "enrollment training system reform", so it is urgent to design the course that satisfies the actual needs of public security law enforcement and improves the students' legal practical ability. At the same time, it can really meet the various requirements of Opinions on Formulating the Professional Scheme of Enrollment Training System Reform Pilot of Public Security Colleges of Ministry of Public Security with regard to talents cultivation in this way.

Principles of curriculum content setting of Administrative Law and Administrative Litigation Law of public security colleges under the background of “enrollment training system reform"

Pay attention to the practicality

After "enrollment training system reform", graduates of public security specialty of public security colleges mainly work in the grass-root public security organs, so its practicality is very important. Adapting to and better serving the public security practice is the public security teaching goal and also the key point of course teaching of Administrative Law and Administrative Litigation Law. Therefore, I think the course teaching of the public security colleges under the background of "enrollment training system reform" should pay more attention to the practicality and pertinence of professional skills of legal science, rather than pursue the theoretical interpretation to be specialized. The talents cultivation aims at creating more values for the state and society. Therefore, the applied talents are important. The course content of Administrative Law and Administrative Litigation Law of public security colleges should be divided, in which attention should be paid to the practical content for the convenience of students' acceptance and to cultivate applied talents.

Stress the basic and common administrative laws and regulations

According to the reality, graduates of public security colleges engage in the administrative management, rather than law enforcement, such as office, political department, supervision department and logistical support, which require the graduates to master the basic knowledge of administrative laws. The first mission of public security organs is to serve the society and people, so 
public security colleges must teach the basic common administrative laws in the course design to make students accept the knowledge of administrative laws required in the future, thus laying a solid foundation for the cultivation of excellent graduates. This does not mean that the teacher should thoroughly teach the theoretical problems and laws and regulations, but that colleges should summarize the knowledge of administrative laws that are common and may be used in the practical public security work, for example, administrative organization, civil servant, administrative chapter and other chapters for the purpose of targeted teaching of students.

Start from the goal that students are competent to the administrative law enforcement after graduation

From the social status, the administrative law enforcement of workers of public security organs mainly involves fighting, prostitution and whoring, gambling, drug abuse and light injury. For an excellent public security officer, it is very important to grasp the knowledge of administrative laws and regulations required by basic administrative law enforcement cases. Therefore, public security colleges should combine the teaching of Administrative Law and Administrative Litigation Law with the actual situation of police officer, especially sort out five types of common cases. In addition, the course should also summarize the difficult and key points of the five types of common cases, deepen and refine the law enforcement procedure, law enforcement measures, entity judgment, procedure application, legal instrument, file processing and other links and combined the knowledge of administrative laws to make students really learn and accept targeted education in classroom and practically use the administrative laws learned. Therefore, from the reality of law enforcement, it should be implemented in the teaching of administrative laws to cultivate public security students that are competent to the administrative law enforcement.

\section{Suggestions on curriculum content setting of Administrative Law and Administrative Litigation Law of public security colleges under the background of "enrollment training system reform”}

\section{Retain the basic framework of the previous knowledge system of Administrative Law and Administrative Litigation Law}

As most students fail to accept this kind of education before entering the public security colleges, so they have no theoretical foundation of this course. To make them clearly know and grasp the course content, the basic framework of the previous knowledge system of Administrative Law and Administrative Litigation Law should be continuously adopted. The course content is divided into four parts: basic theory of administrative law, administrative subject, administrative behavior and administrative supervision and remedy, in which basic theory of administrative law mainly teaches the basic problems of administrative law, including administration, administrative law, administrative legal relations and basic principles of administrative laws and other important contents; administrative subject mainly includes the relevant knowledge of administrative subject, administrative organ, authorized organization, entrusted organization, civil servant and administrative counterpart; administrative behavior mainly includes the basic theory of administrative behavior, abstract administrative behavior, specific administrative behavior and administrative procedure; administrative supervision and remedy mainly includes administrative legal supervision, administrative compensation, administrative reconsideration, administrative litigation and other content. The course construction system is: what's Administrative Law and Administrative Litigation Law - which units and individuals are the course content suitable for what's the legal relations of these units and individuals - how to settle the dispute in the process. The knowledge system has a clear knowledge framework, which is convenient for teachers' interpretation and also for students' understanding and mastering. Therefore, Administrative Law and Administrative Litigation Law of public security colleges under the background of "enrollment training system reform” should retain the basic framework of original knowledge system. 


\section{Integrate the teaching content scientifically, reasonably and specifically}

Next is the selection of specific teaching content. The course content of Administrative Law and Administrative Litigation Law should be closely combined with the cultivation goal of this course, fully consider the needs of practical administrative law enforcement work of public security officers and conduct scientific, reasonable and targeted integration of specific teaching content. After "enrollment training system reform” of Ministry of Public Security, the talents training scheme is attached to course teaching content of Administrative Law and Administrative Litigation Law in table 3. The practical training project of this course should include case acceptance, proper application of compulsory administrative measures, investigation and evidence collection, proper application of informing procedure, organization of testacy proceeding, participation of administrative case trial and other contents. In addition, the theoretical knowledge should be divided into three parts: first, detailed teaching of basic concepts of administration, administrative law and administrative relations as well as basic principles of administrative law and brief teaching of development history of administrative laws and theoretical comparison and other problems; second, analysis and teaching of domestic current administrative subject to make students know the domestic current administrative systems and grasp the authority and responsibility of administrative organ, authorized organization and entrusted organization in the exercise of administrative right; third, stress on legal and effective conditions of administrative behavior, administrative punishment, administrative arbitrariness, administrative inspection and other specific administrative behaviors of public security administrative law enforcement according to the administrative procedure.

\section{Properly involve the practical training by course content}

As "practice is the sole criterion for testing truth", the course content of Administrative Law and Administrative Litigation Law of public security colleges under the background of "enrollment training system reform” should involve the practical training. After theoretical knowledge teaching and conventional theoretical test, the situation that may be encountered by public security officers in the practical administrative law enforcement, such as fighting and gambling, can be simulated to investigate students' knowledge mastering, which is a kind of ability test. Then, according to the performance of different students in the investigation, the problems encountered by most students in the practical administrative law enforcement and knowledge vulnerabilities of students can be summarized for reeducation. The problems of students that cannot be found can be exposed in the practice for the purpose of targeted education of students and vulnerability optimization education of students, which is also conducive to the knowledge mastering of students and make students realize their vulnerabilities so as to enhance their study of relevant knowledge. Therefore, Administrative Law and Administrative Litigation Law of public security colleges under the background of "enrollment training system reform" should involve the proper practical training to help teachers know their teaching vulnerabilities and modify their teaching mode and contents and also help students realize their mastering of knowledge and conduct targeted learning according to the reality. All in all, Administrative Law and Administrative Litigation Law of public security colleges under the background of "enrollment training system reform" should involve the practical training, which is conducive to improve students' administrative law enforcement ability and cultivate more excellent applied talents for the state and society.

\section{Conclusion}

In conclusion, the three principles that the course setting of Administrative Law and Administrative Litigation Law must follow, that is, pay attention to the practicality, stress the basic and common administrative laws and regulations, start from the goal that students are competent to the administrative law enforcement after graduation, are summarized by analyzing and discussing the necessity and guiding thought of research on course content of Administrative Law and Administrative Litigation Law of public security colleges, and then it is proposed to retain the basic framework of the previous knowledge system of Administrative Law and Administrative Litigation Law and integrate the teaching content scientifically, reasonably and specifically based on this. 
Under the background of "enrollment training system reform”, public security colleges should reform the course content of Administrative Law and Administrative Litigation Law in a targeted manner to satisfy the requirements of domestic current administrative systems and cultivate more excellent public security officers for the state.

\section{Acknowledgments}

This paper is the undergraduate education teaching reform research project of Liaoning provincial ordinary colleges in 2014, project name: Practical Teaching Reform of Administrative Law of Public Security Colleges under the Background of "Enrollment Training System Reform”, project number: UPRP20140252, project leader: Wang Qiao.

\section{References}

[1] Guan Baoying. Cognition of Analytic Logic of Administrative Law. China Legal Science, 2014,(10):17-19

[2] Xie Tianchang, Wu Qing. Discussion on Teaching Content Setting of Administrative Law. Legal Education Research, 2013,(2):24

[3] Jin Long. On Knowledge System of Administrative Law from Public Management Perspective. Legal Science Curriculum, 2014,(3):13-15

[4] Ying Songnian, Wang Jing. Research Overview of Administrative Law with Sound Development. China Legal Science, 2013,(12):26-27

[5] Wang Longtian. Research on Legal Problems of Graduation Practice of Students from Public Security Colleges. Police Education and Training,2011,(11):34-36 